\title{
LIVING QUR'AN DI TENGAH PANDEMI COVID-19 DALAM PEMBELAJARAN AL-QURAN DARING PERSPEKTIF NEUROSAINS
}

\author{
Rina Sarifah dan Suyadi \\ Universitas Ahmad Dahlan Yogyakarta \\ Email : rina2007052013@webmail.uad.ac.id, suyadi@fai.uad.ac.id
}

\begin{abstract}
ABSTRAK
Pandemi Covid-19 telah memengaruhi banyak kebijakan pemerintah termasuk model pembelajaran dari Mekanisme administrasi hingga sistem komunikasi. Pemerintah mengimbau masyarakat untuk bekerja di rumah, belajar hingga beribadah di rumah. Seluruh tempat yang mengundang banyak massa ditutup. Begitu juga dengan sekolah, sebagai satuan pendidikan, yang otomatis menjadi tempat berkumpul bagi warga yang secara permanen terkena dampak kebijakan untuk mencegah virus COVID-19 berkumpul. Dengan adanya fenomena tersebut maka penulis mengambil sebuah latar belakang mengenai pola belajar mengaji anak selama pandemi covid-19 ini berlangsung. Dengan seluruh kegiatan yang dilakukan di rumah seharusnya tidak menjadikan seorang anak terpuruk dan meninggalkan al-Quran. Namun dengan bimbingan orang tua di rumah seharusnya seorang anak mampu untuk melanjutkan belajar mengajinya di rumah bersama orang tua dan orang-orang terdekatnya di rumah. Perubahan perilaku ini berpengaruh kepada kehidupan sehari-hari menurut neurosains. Penelitian ini menggunakan penelitian lapangan dengan jarak jauh dilakukan pengisian angket untuk mengetahui sejauh mana perilaku seorang anak berubah mengenai pendidikan al-Quran. Karena sejak pandemi covid-19 berlangsung kegiatan Taman Pendidikan Al-Quran ditiadakan sehingga terjadi perilaku belajar al-Quran anak di masa pandemi covid-19 dalam prespektif neurosains yang berubah.
\end{abstract}

Kata Kunci : Belajar, Al-Quran, Covid-19, Neurosains

\begin{abstract}
Pandemic covid -19 has influenced many government policy include learning model and administrative mechanism until commuication system. Gevornment appealed general public to working from home, study until worship all from home. All places make many people to collect are closed. So is with school, as education units, which automatically becomes a gathering place for residents who are permanently affected by policies to prevent the COVID-19 virus from gathering. With this phenomenon, the authors took a background regarding the learning pattern of children in the al-Quran during the Covid-19 pandemic. However, with the guidance of parents at home, a child should be able to continue learning to teach at home with parents and those closest to him at home. Change in this behavior take effect with the everyday life according ro neuroscience This study used field research with long distance which done by using filling out the questionnaire for knowing extent of behavior child can changes about alQuran education. Because since pandemi covid-19 the Al-Quran Education Park activity has been eliminated so that children can see the learning patterns of the alQuran for children during the Covid-19 pandemic in a neuroscience perspective.
\end{abstract}

Keyword: Study, Al-Quran, Covid-19, neuroscience 


\section{PENDAHULUAN}

Untuk pertama kalinya Indonesia bahkan dunia mengalami kejadian yang sangat luar biasa dimana karena seluruh kehidupan manusia berubah. Dimulai dari cara makan, beribadah hingga berkumpul semua dibatasi. Ini semua terjadi karena adanya wabah virus covid-19 yang menyerang seluruh bagian negara di dunia. Setiap negara berbeda-beda cara menangani virus ini. Seperti di Korea Utara akan menembak mati bagi pasien yang terinfeksi virus ini atau bahkan memberikan hukuman kerja paksa bagi warganya yang tidak menggunakan masker. Ini terbilang efektif karena terbukti di Korea Utara tidak terdapat pasien suspec covid-19. Namun cara penanganan Korea Utara untuk menekan wabah virus ini tidak dapat digunakan di Indonesia. Karena Indonesia masih mengedepankan hak asasi manusia. Cara pemerintah Indonesia menekan tingginya penderita covid-19 ini adalah dengan $3 \mathrm{M}$ yaitu memakai masker, mencuci tangan dan menghindari kerumunan. Hal inilah yang menimbulkan kebiasaan warga Indonesia berubah. Semua tempat yang menghadirkan massa akan dibubarkan. Begitu juga dengan jamaah shalat dan pengajian semua dibatasi untuk kepentingan bersama.

Efek yang ditimbulkan oleh Covid-19 sangatlah berpengaruh di semua lini kehidupan. Termasuk di sekolah-sekolah. Banyak negara yang menghentikan kegiatan belajar di sekolah ini semua dilakukan untuk mengurangi mobilitas masyarakat di luar rumah. Dampak covid-19 di di dunia pendidikan jangka pendeknya yaitu banyaknya keluarga yang belum siap untuk menjadi guru di rumah bagi anak-anaknya karena telah terbiasa melakukan kegiatan belajar di sekolah. (Kasfianti Zulhaenah, 2021 : 239)

Ketika siswa belajar di rumah menjadi sebuah masalah bagi orang tua karena tugas mereka di rumah bertambah yaitu berperan menjadi seorang guru di rumah. Tugas utama mereka untuk mencari nafkah yang juga dilakukan di rumah ditambah harus menjadi guru bagi anak-anak mereka merupakan kecemasan tersendiri. Ketidakmampuan dalam menghadapi perubahan besar ini harus tetap dijalani karena bahaya covid-19 sangatlah berbahaya bagi diri sendiri juga orang lain. (Iin Nurbudiyan, Rita Rahmaniati, Agustinawati Umaternate, Rabiatul Adawiyah, $2021: 430$ ) 
Diketahui dari laman website sehatQ mengatakan terdapat 4 golongan yang rentan terpapar covid-19 yaitu orang tua yang telah lanjut usia, orang yang mempunyai riwayat penyakit tertentu, tenaga medis rumah sakit dan anak-anak. Inilah sebab mengapa akhirnya sekolah diliburkan yaitu untuk mempersempit ruang gerak dari wabah covid-19 ini. Semua warga Indonesia dihimbau agar tidak keluar rumah dan melakukan segala kegiatan cukup dari rumah saja baik itu bekerja, sekolah bahkan mengaji. Kegiatan mengaji yang biasanya dilakukan di masjid maupun taman pendidikan al-Quran harus berhenti dan dilakukan di rumah dengan keluarga. Bagi yang memungkinkan terdapatnya signal yang memungkinkan maka belajar mengaji dapat dilakukan dengan daring yaitu melalui video call. Namun di tempat yang berbeda mengharuskan orang tua untuk terus mendampingi anaknya belajar mengaji. Bukan hal mudah mengajarkan anak untuk mencintai al-Quran. karena pada kenyataannya banyak anak yang akhirnya berhenti mengaji karena merasa tidak nyaman dengan orang tua yang mengajarkannya.

Perilaku ini membuktikan bahwa perilaku seseorang dapat berubah-ubah sesuai dengan kebiasaan yang dibangunnya sejak kecil. Karena neurosains perilaku memeriksa bagaimana berbagai sistem saraf menghasilkan perilaku tertentu dengan bekerja. Misalnya, bagaimana saraf optik, saraf pendengaran, dan saraf motorik secara bersamaan memproses informasi.

Menurut (Wathon, 2016) dalam jurnalnya menjelaskan neurosains mempelajari manusia dalam arti keseluruhan, termasuk mempelajari perilaku dengan memahami pengoperasian sel saraf, terutama interaksi antara otak, tubuh, dan jantung. Fokus utama ilmu saraf adalah neurogenetika dan biologi sistem, yaitu ilmu yang membahas struktur dan fungsi khusus persarafan dengan cara yang lebih makroskopis. Berkaitan dengan hal tersebut, termasuk mikrostruktur sel saraf dan bagaimana sel saraf tersebut saling berhubungan membentuk sirkuit (wiring diagram), ruang lingkup penelitian neurosains yang masih sangat luas.

\section{METODE}

Metode yang digunakan dalam penulisan karya ilmiah ini adalah penelitian lapangan. Penelitian lapangan 
ini digunakan untuk mengetahui minat siswa kelas 1-6 SD dalam membaca alQuran di masa pandemi covid-19. Metode penelitian yang meliputi langkah-langkah, argumentasi, dan proses yang sistematis, serta harus didukung oleh data yang akurat. Studi kasus ini bertujuan untuk mengkaji secara mendalam konteks situasi terkini dan interaksi masyarakat, individu, kelompok, lembaga, dan masyarakat. Penelitian ini bertujuan untuk mendeskripsikan bagaimana pola belajar al-Quran anak pada masa pandemi covid-19 menurut neurosains agar dapat memberikan tindak lanjut lebih baik dalam mempelajari al-Quran. pada penelitian ini penulis mengambangkan survei online yang dilaksanakan sejak tanggal 5-16 Desember 2020. Untuk mendapatkan data mengenai pola belajar al-Quran anak semenjak adanya wabah covid-19. Sampel yang didapatkan oleh penulis merupakan siswa yang rata-rata duduk di kelas 1 hingga kelas 6 SD yang tersebar di Kulon Progo Yogyakarta sebanyak 110 anak. Survei dilakukan dengan cara memberikan pertanyaan online dengan media google form. Pertanyaan yang diajukan meliputi kegiatan belajar mengaji mereka sebelum dan setelah pandemi covid-19. Sehingga dapat diketahui perilaku belajar mengaji al-Quran mereka apakah meningkat ataupun menurun yang akhirnya semua berhubungan dengan ilmu neurosains.

\section{HASIL DAN PEMBAHASAN}

Sebelum datangnya virus covid19 ke negara Indonesia kehidupan manusia berjalan dengan normal. Semua orang bebas untuk berkumpul dan berinteraksi antara satu dengan lainnya. Namun semenjak munculnya covid-19 mengakibatkan setiap orang menjadi lebih kuatir untuk menjalani aktivitas sehari-hari mengingat potensi peningkatan risiko yang ditimbulkan oleh penyakit tersebut sangatlah berbahaya.

Kajian pustaka merupakan bagian yang sangat penting dalam penelitian ilmiah karena bagian ini mengungkapkan gagasan atau teori yang menjadi dasar laporan atau penelitian ilmiah tersebut. Teori yang disajikan disini menjelaskan hubungan antara beberapa konsep yang digunakan untuk menjelaskan sebuah karya ilmiah. Disebut tinjauan pustaka, yaitu kegiatan yang meliputi pencarian, pembacaan dan pengecekan laporan penelitian atau 
karya ilmiah dan bahan pustaka yang memuat teori-teori yang berkaitan dengan penelitian yang akan dilaksanakan. Kegiatan ini merupakan bagian penting dari metode ilmiah dan harus dilaksanakan dalam setiap penelitian. Hasil dari kegiatan ini berupa materi yang akan diusulkan untuk meletakkan landasan atau kerangka bagi teori atau karya ilmiah penelitian, dan akan dikenalkan pada bab tinjauan pustaka dalam rencana penelitian atau laporan atau karya ilmiah. Berikut ini akan disajikan terkait dengan pola belajar al-Quran anak di masa pandemi covid-19 menurut neurosains. Berdasarkan permasalahan dan metode diatas, penulis telah melakukan penelitian untuk menemukan solusi masalah dengan menganalisis data yang diolah. Dimana pola belajar anak sebelum pandemi covid-19 adalah:

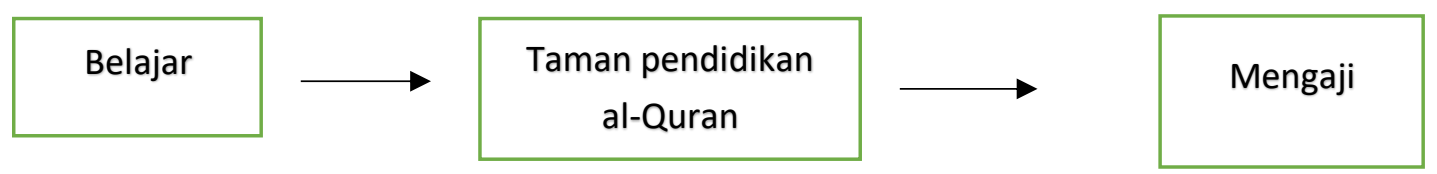

Gambar 1. pola belajar al-Quran anak sebelum pandemi covid-19

1. Belajar sejatinya dilakukan oleh siapapun dan dimanapun. Belajar merupakan proses ketidaktahuan menjadi berpengetahuan. Menurut Bahril (2017) Islam memerintahkan penganut agamanya untuk melanjutkan proses belajar hingga akhir hayatnya. Salah satu metode pembelajaran yang dikenal dalam Islam adalah membaca. Sejak awal Islam metode membaca telah menjadi salah satu metode atau teknik dasar dalam proses belajar individu. Sebagai umat Muslim kita meyakini bahwa wahyu pertama yang diterima oleh Rasulullah saw adalah 'iqro yaitu bacalah. Yang telah dijelaskan oleh para mufassirin bahwa dalam wahyu ini menegaskan agar umat muslim berusaha untuk belajar dan menuntut ilmu.

2. Taman pendidikan al-Quran yaitu salah satu tempat untuk mencari ilmu agama. Dimana bertemunya seorang Guru dengan para murid-muridnya untuk belajar membaca al-Quran, menghafal al-Quran serat kegiatan keislaman lainnya 
3. Mengaji merupakan kegiatan menambah ilmu membaca al-Quran yang biasa dilakukan sejak dini dengan awal belajar membaca alQuran yaitu dimulai dari iqro.

Pada gambar penjelasan tersebut terlihat bahwa kegiatan belajar mengaji di Taman Pendidikan Al-Quran bukan hanya membaca al-Quran saja namun juga dapat dilakukan sharing dengan teman-teman lainnya dan dapat berinteraksi juga. Namun setelah adanya pandemi covid-19 yang segala sesuatunya diubah dengan menghindari kerumunan maka Taman Pendidikan Al-Quran ditutup dan semua kegiatan belajar mengaji dilanjutkan oleh orang tua di rumah.

Pada batasan penelitian ini yaitu penelitian ini menggunakan media google form pada link https://forms.gle/zJVjXZS8AUWp5cA

A8 dengan para responden yang acak dengan jangka waktu satu pekan dengan responden 110 anak pada tingkat SD kelas 1 hingga kelas 6 SD yang berada di Kulon Progo. Dengan pertanyaan yang diajukan mengenai pola belajar mengaji anak sebelum dan setelah pandemi covid-19. Karena sedikit banyak dengan adanya pandemi covid19 ini sangat berpengaruh pada pola belajar mengaji anak yang sebelum pandemi covid-19 dilaksanakna di luar rumah dengan bertemu banyak teman namun setelah adanya pandemi covid19 semua kegiatan dilakukan di rumah yang pasti menimbulkan kejenuhan saat belajar mengaji. Baik di rumah maupun di tempat lainnya Output yang diperoleh adalah sama yaitu kemampuan membaca al-Quran. namun terdapat perbedaannya yaitu jika seorang anak belajar di rumah maka akan lebih cepat jenuh sehingga target bacaan alQurannya tidak mudah didapatkan ketika mereka melakukannya di Taman Pendidikan al-Qutan. Hal tersebut dapat dilihat dari survei yang telah dilakukan.

Telah dilakukan survei mengenai pola belajar mengaji anak pada tingkat SD kelas 1 hingga kelas 6 SD sebelum pandemi covid terjadi. Dimana sebelum pandemo covi-19 terjadi tidak semua anak mengaji baik itu di rumah, taman pendidikan al-quran, masjid, musholla maupun di Diniyah, ini merupakan suatu masalah. Karena mengaji merupakan salah satu bentuk ibadah kita kepada Allah swt. pada survei tersebut dari 110 anak yang mengisi masih terdapat 5 anak yang tidak belajar mengaji. Sedangkan 103 anak lainnya belajar mengaji yang dilakukan di 
rumah, di taman pendidikan al-quran, masjid, musholla dan juga di diniyah maupun pondok pesantren.

Sedangkan ketika memasuki masa pandemi covid-19 terdapat sedikit perbedaan mengenai pola belajar mengaji anak yang terlihat pada tabel berikut:

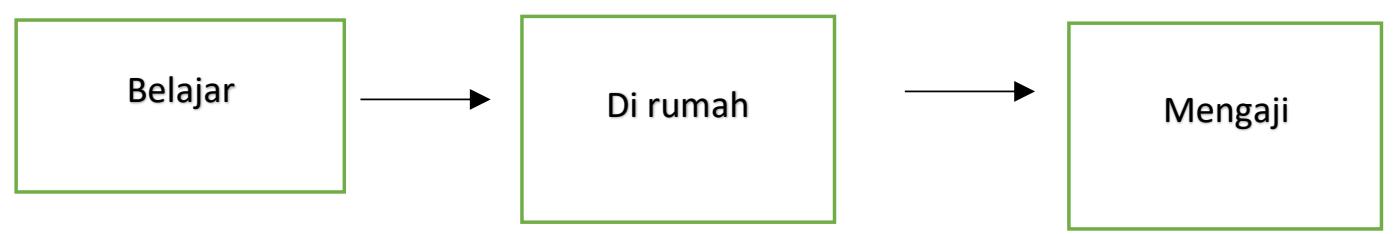

Gambar 3. pola belajar al-Quran anak setelah pandemi covid-19

Setelah pandemi covid-19 terjadi semua tempat yang menghadirkan massa untuk sementara waktu dinonaktifkan hal ini dilakukan untuk menghidari penyebaran virus covid-19 yang korbannya semakin hari semakin bertambah dan untuk menghindari cluster tempat ibadah. Dimana di Taman pendidikan al-Quran terdapat anak-anak yang rentan tertular wabah dari viru s covid-19 ini. Ketika semua kegiatan anak dilaksanakan di rumah pastinya tidak semulus harapan. Karena seorang anak yang terbiasa bertemu dengan teman-temannya kini harus belajar bersama orang tua. Hal ini dapat terlihat dari survei angket yang telah disebarkan

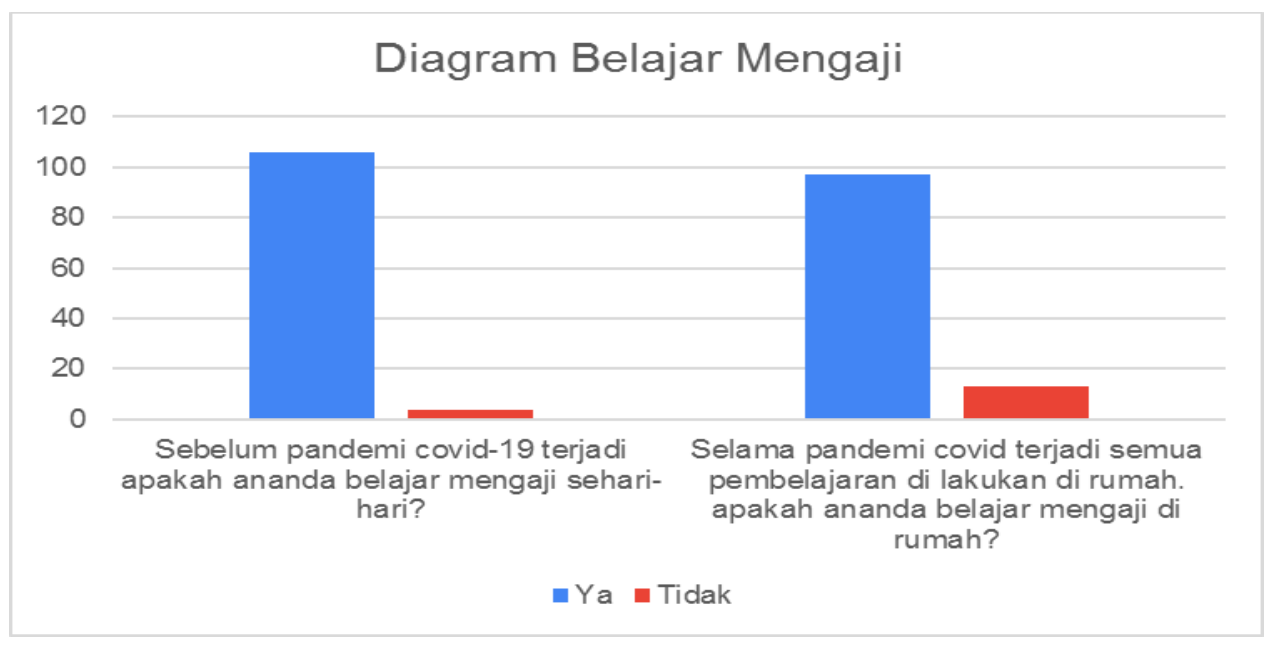

Gambar 3. hasil survei pola belajar pola al-Quran anak setelah pandemi covid-19 
Pada hasil survei di atas terdapat penurunan untuk pola belajar mengaji anak di rumah. dapat terlihat hasil diagramnya menunjukkan $87,3 \%$ atau 96 anak yang masih setia mengaji sedangkan $12,7 \%$ atau 14 anak tidak mengaji sama sekali. Terjadi peningkatan bagi anak-anak yang tidak mengaji. Walaupun peningkatan tersebut tidak banyak namun secara otomatis akan mempengaruhi target mengaji mereka. Karena seharusnya sesuai peraturan daerah di Kulon Progo minimal anak kelas 6 SD telah khatam al-Quran.

Media yang digunakan selama pandemi berlangsung juga mempengaruhi pola belajar mengaji anak-anak. Dimana tidak semua anak belajar mengaji dengan cara tatap muka namun juga dilakukan dengan cara online dengan media WA melalui Video call. Namun dari hasil pertanyaan yang saya ajukan terdapat banyak pendapat yang menyatakan kebosanannya belajar di rumah. Bahkan terdapat anak yang beranggapan kebosanannya karena saat online harus berakting. Namun ada juga yang terus berharap dimana saja mengaji yang penting Allah memberikan kemudahan. Belajar mengaji secara tatap muka yang dilaksanakan oleh anak-anak tersebut disimak oleh para Guru baik yang berkenan datang ke rumah. dan juga disimak oleh orang tua, kakak dan juga saudara.

Peran orang tua yaitu Ibu dan Bapak juga saudara yang tinggal satu rumah sangatlah kuat. Karena dengan arahan orang-orang terdekat di rumah maka pola belajar mengaji anak akan terkontrol sehingga target mengajinya dapat terselesaikan. Dengan anak-anak melanjutkan belajar mengaji mereka di rumah maka akan mempermudah diri mereka sendiri untuk mencapai targetnya. Untuk itu kita wajib menanamkan karakter al-Quran pada anak karena karakter al-Qur'an merupakan tindakan menanamkan nilai Al-Qur'an kepada manusia, sehingga mewujudkan akhlak yang mulia sesuai dengan makna Al-Qur'an. Ini semua dapat dilakukan secara online maupun ofline. Setiap melakukan hal yang baik tentunya harus memiliki motivasi dan mengembangkan karakter sendiri, seorang anak harus termotivasi dan terbiasa dengan karakter yang ingin dicapai.

Perubahan sikap anak untuk belajar mengaji menjadi menurun berhubungan dengan ilmu neurosains. 
Menurut (Awhinarto, 2020) Neurosains merupakan ilmu saraf atau sering disebut juga dengan istilah neuroscience yang mempelajari tentang sistem saraf khususnya neuron atau neuron secara multidisiplin. Secara umum ilmu saraf merupakan salah satu cabang ilmu biologi, kemudian berkembang dan menyebar ke berbagai cabang ilmu lainnya, seperti psikologi, biokimia, fisiologi, farmakologi, informatika, ilmu komputer, statistika, fisika, dan kedokteran. Tujuan dari ilmu saraf adalah mempelajari dasar biologis dari setiap perilaku manusia. Dengan kata lain, tugas terpenting di bidang ilmu saraf adalah menjelaskan perilaku manusia dari sudut pandang aktivitas otak. Otak merupakan organ manusia yang sangat penting, sehingga fungsi pengaturan otak memiliki pengaruh yang besar terhadap tingkah laku atau perilakunya. Tingkah laku manusia pada dasarnya dikendalikan oleh sistem syaraf di otak, sehingga semua tingkah laku manusia justru akan menyebabkan otak berfungsi penuh, sehingga memberikan rangsangan atas rangsangan yang dilakukan. Apa pun yang berpotensi meningkatkan kinerja otak harus dipertimbangkan sebagai bagian penting. Salah satu cara untuk meningkatkan kualitas otak manusia adalah melalui proses pendidikan yang mengarah pada perilaku, dalam hal ini proses pendidikan.

Dalam pembelajaran pendidikan agama Islam, perkembangan kecerdasan emosional dapat dilihat dari semua aspek kecerdasan emosional yaitu empati, rasa hormat, mengungkapkan dan memahami perasaan, mengelola emosi, kemampuan memecahkan masalah interpersonal, keramahan, motivasi, kemandirian, ketekunan dan adaptasi. kemampuan. Metode yang digunakan guru untuk mengembangkan kecerdasan anak selama proses pembelajaran meliputi ceramah, metode tanya jawab, metode diskusi, metode kerja kelompok, metode pekerjaan rumah, disiplin dan ketepatan waktu, serta pembacaan doa dan Alquran sebelum pembelajaran. (Wulandari \& Suyadi, 2019)

Secara umum, struktur otak terdiri dari dua belahan (kiri dan kanan), yang mengontrol berbagai fungsi otak, seperti berpikir, abstraksi, dan bahasa. Anatomi otak yang terbagi menjadi dua bagian yaitu otak atau yang disebut otak depan, bukan seluruh otak itu sendiri. Selanjutnya otak membentuk lobus di bagian luar otak. Kemudian di bagian 
tengah adalah talamus. Talamus adalah gumpalan saraf sensorik di sekitar tubuh yang mengirimkan informasi ke bagian otak yang lain. (Afria Nursa \& Suyadi, 2020)

Sedangkan Penelitian tentang otak menunjukkan teori belajar dalam banyak hal, model ini tampaknya menangkap dunia nyata lebih baik daripada model minimalis. Fungsi otak memiliki banyak muatan yang tidak perlu, yang menjelaskan temuan umum. Temuan ini menunjukkan bahwa ketika area otak yang diketahui terkait dengan fungsi tertentu terpengaruh, fungsi itu mungkin tidak hilang sama sekali. (Wijaya Hengki, 2018)

Menurut Uno "Pada pelaksanaannya baik belajar secara jarak jauh secara online maupun belajar tatap muka langsung (offline) tetap harus memperhatikan tercapainya tujuan pembelajaran. Merujuk pada pendapat Robert F. Mager”. (Kurniasari, 2020)

Sedangakan menurut Uno secara lebih lanjut mengatakan "tujuan pembelajaran adalah perilaku yang hendak dicapai atau yang dapat dikerjakan oleh siswa pada kondisi dan tingkat kompetensi tertentu. Kemp dan Kapel.” (Kurniasari, 2020)
Sedangkan Henry Ellington dalam Hamzah B. Uno menyebutkan bahwa "tujuan pembelajaran adalah suatu pernyataan spesifik yang dinyatakan dalam perilaku atau penampilan yang diwujudkan dalam bentuk tulisan untuk menggambarkan hasil belajar yang diharapkan.” (Kurniasari, 2020)

Penggunaan gabungan sumber daya tradisional (offline) dan sumber belajar online merupakan keputusan demokratis yang bertujuan untuk menjembatani distribusi cepat sumber daya e-learning (e-learning) dan menghilangkan kesulitan sumber belajar yang digunakan di ruang kelas. Dengan kata lain, apapun teknologi yang digunakan, e-learning tidak dapat menggantikan realisasi pembelajaran tatap muka, karena metode interaksi tatap muka tradisional masih lebih efektif daripada pembelajaran online atau e-learning. (Dwi et al., 2020)

Menurut Wilis pada jurnalnya mengatakan "Para ahli pendidikan menyambut positif penetrasi Neurosains untuk pendidikan. Guru mempunyai hak istimewa dan kesempatan meningkatkan kualitas dan kuantitas jalur penghubung neuronal agar otak mereka dapat dioptimalkan untuk kesuksesan masa depan. Untuk itu pemahaman 
Neurosains untuk guru dengan menerapkannya kedalam program pendidikan guru." (Rivalina, 2020)

Dalam hal perkembangan anak, al-Quran dapat berperan penting dalam meningkatkan potensi anak untuk berkembang sesuai minat dan bakat masing-masing. Anak kecil, termasuk cendekiawan, peneliti, praktisi dan orang tua, harus memperhatikan proses belajar al-Quran. Untuk itu diperlukan penelitian interdisipliner, khususnya psikologi agama dan ilmu saraf. (Hidayat, 2017)

Sedangkan Lynch beranggapan "Guru perlu merancang dan mensinerjikan neurosains dalam pembelajaran. Memahami perkembangan anak usia dini, sekolah dasar, anak autis, berkebutuhan khusus, dan sulit belajar. Anak harus memiliki waktu tidur yang cukup dan perlu jeda waktu pembelajaran yang rumit. Melakukan gaya belajar pengulangan dan beragam pendekatan." (Rivalina, 2020)

Sesuatu yang bisa merangsang dan memberi anak ruang terbesar untuk mengembangkan kemampuan mereka, yaitu Ilmu Saraf. Neurosains dapat digunakan dalam pembelajaran agama Islam, yang terkenal dengan metode ingatan, ceramah, dll. Melalui desain pembelajaran agama berbasis ilmu saraf ini, kita dapat memahami preferensi intelektual anak dalam hal perilaku, kemampuan belajar, dan emosi mereka. Dalam bidang ilmu saraf, pembelajaran merupakan pelengkap kurikulum yang sudah ada. Metode penerapan yang menarik, terutama karena kerjasama antara ilmu agama Islam dan pendidikan umum, menjadi salah satu dasar kemampuan belajar siswa. Oleh karena itu, program pembelajaran agama berbasis neurosains ini diharapkan dapat memberikan solusi atas kurangnya pemahaman guru terhadap karakter atau keinginan siswa untuk belajar. (Saifurrahman, 2019)

Membangun sistem pendidikan karakter yang baik tentunya perlu memasukkan ilmu saraf dalam pendidikan, karena jika hanya bisa bertahan dalam pembelajaran berbasis behavioris, maka pendidikan akan berkembang perlahan. Dari perspektif anak yang berbeda, jika dalam waktu ini Hanya pembiasaan yang akan mengakibatkan otak siswa tidak digunakan untuk belajar. Oleh karena itu, pendidikan perlu memperhatikan dan memasukkan ilmu saraf ke dalam pembelajaran. (Of \& Education, 2020) 
Dunia pendidikan Islam harus berorientasi pada kinerja rasional. karena hasil pendidikan Islam dapat mengarah pada tujuan pendidikan dasar, meskipun manusia memiliki keunggulan dan kemampuan beradaptasi setelah memikirkan alQuran, kemudian mengamalkannya, dan memiliki kemampuan yang kuat dalam membaca, berpikir, dan berinovasi. Pahami fenomena kosmik dan terapkan dalam kehidupan sehari-hari. Perbaiki hari-hari kehidupan manusia. Di sisi lain, melalui orientasi pengaktifan rasionalitas, pendidikan Islam diharapkan mampu membentuk manusia yang berakhlak mulia, berakhlak mulia terhadap sesama, dan bertakwa kepada Allah SWT menurut (Rofdli, 2020).

Maka dari dapat ditarik kesimpulan bahwa pola belajar sebelum pandemi berlangsung sangat diminati oleh anak-anak sehingga target belajar mereka dapat tercapai dengan lebih cepat. Hal ini berhubungan dengan neurosains dimana otak berusaha untuk belajar dan mampu mencapai target mengaji al-Quran. Dari hasil pola belajar mengaji al-Quran anak sebelum dan setelah terjadinya pandemi covid-19 maka terdapat koneksitas dengan ilmu neurosains.

Perilaku dan perubahan sikap harus dilandasi utama yaitu perubahan cara berpikirnya, karena otak manusia selalu berkembang dan bisa menjadi lebih baik atau lebih buruk. (Margono, 2018)

Terdapat banyak faktor yang menyebabkan seorang anak tidak lagi fokus pada mengajinya. Faktor yang menyebabkan menurunnya minat seorang anak untuk mengaji di masa pandemi covid-19 ini bermacam-macam dari rasa kebosanan yang hanya di rumah bersama orang tua, hal ini juga diperkuat oleh pernyataan (Wathon, 2016) yaitu Banyak anak tidak belajar dengan baik hanya untuk menyenangkan guru atau orang tuanya. Ketidaktahuan orang tua dan guru terhadap ilmu otak (neurobiologi) anakanak yang menyebabkan kesalahan dalam pendidikan anak usia dini. Akibatnya potensi alam tidak dapat dikembangkan dengan baik. Oleh karena itu, sudah sepatutnya guru dan orang tua memahami cara kerja dan perkembangan alamiah otak anak. Dengan ilmu tersebut, guru dan orang tua dapat bekerja keras untuk merangsang perkembangan otak anak, 
sehingga fungsi alaminya dapat berkembang.

\section{KESIMPULAN}

Setelah pandemi covid-19 terjadi semua tempat yang menhadirkan massa untuk sementara waktu dinonaktifkan hal ini dilakukan untuk menghidari penyebaran virus covid-19 yang korbannya semakin hari semakin bertambah dan untuk menghindari cluster tempat ibadah. Yang secara otomatis di Taman pendidikan al-Quran terdapat anak-anak yang rentan tertular wabah dari virus covid-19 untuk sementara waktu juga ditutup. Sehingga seorang anak yang terbiasa bertemu dengan teman-temannya kini harus belajar bersama orang tua. dapat terlihat hasil diagramnya menunjukkan $88 \%$ atau 95 anak yang masih setia mengaji sedangkan $12 \%$ atau 13 anak tidak mengaji sama sekali. Sehingga terjadi peningkatan bagi anak-anak yang tidak mengaji.

Ilmu neurisains atau ilmu saraf adalah bidang ilmu yang mempelajari bidang otak sistem dan dinamika sistem saraf. Ilmu tersebut sangat penting karena dapat membentuk bangsa yang sehat dan kuat terutama demi kemajuan dan keunggulan bangsa dan negara yang memasuki era persaingan masyarakat ekonomi Asia. Neurosains adalah salah satu cabang ilmu yang berfokus untuk mengenal lebih jauh mengenai otak dan sistem saraf. Berbagai modul dan teori dapat dengan mudah diaplikasikan bagi siapa saja terutama untuk anak. Ilmu terapan neurosains mampu menstimulus untuk mencerdaskandan mengoptimalisasikan kemampuan anak.

Dengan menitikberatkan pada pentingnya peran otak bagi manusia dalam praktik pendidikan Islam termasuk belajar mengaji al-Quran, maka pendidikan karakter Islam harus berusaha menjadikan otak sebagai pusat pendidikan. Sehingga dengan adanya pandemi covid-19 ini bukan menjadi suatu alasan bagi kita para pendidik untuk terdiam dan mengikuti arus, namun dengan kemajuan tekhnologi kita mampu memanfaatkannya dan membuat suatu terobosan agar menekan anak-anak kita yang malas dalam belajar membaca al-Quran.

\section{DAFTAR PUSTAKA}

Afria Nursa, R., \& Suyadi, S. (2020). Konsep Akal Bertingkat Al-Farabi Dalam Teori Neurosains Dan Relevansinya Dengan Pendidikan Islam. Tawazun: Jurnal Pendidikan Islam, 13(1), 1. https://doi.org/10.32832/tawazun. v13i1.2757 
Awhinarto, S. (2020). Otak Karakter dalam Pendidikan Islam. 143156. http://library1.nida.ac.th/termpape r6/sd/2554/19755.pdf

Dwi, B., Amelia, A., Hasanah, U., \& Putra, A. M. (2020). Analisis Keefektifan Pembelajaran Online di Masa Pandemi Covid-19. Jurnal Pendidikan Guru Sekolah Dasar, 2(1), 3.

Hidayat, B. (2017). Pembelajaran Alquran pada Anak Usia Dini Menurut Psikologi Agama dan Neurosains. Proceedings of The 2nd Annual Conference on Islamic Early Childhood Education, 2, 60.

Iin Nurbudiyan, Rita Rahmaniati, Agustinawati Umaternate, Rabiatul Adawiyah, I. H. (2021). Ketahanan Keluarga Dalam Menghadapi Pandemi Covid-19 dan Paska Covid-19 di Kelurahan Sabaru Kalimantan Tengah. Jurnal Pengabdian Al-Ikhlas, 6(April), 5-24.

Kasfianti Zulhaenah, Y. N. (2021). Pendampingan dan Peningkatan Kecakapan Guru Dalam Inovasi Pembelajaran Daring di Tengah Pandemi Covid-19. Jurnal Pengabdian Al-Ikhlas, 6, 5-24.

Kurniasari, A. dkk. (2020). Analisis Efektivitas Pelaksanaan Belajar Dari Rumah (Bdr) Selama Pandemi Covid-19. Jurnal Review Pendidikan Dasar: Jurnal Kajian Pendidikan Dan Hasil Penelitian, 6(3), 1-8.

Margono, B. S. (2018). Integrasi Neurosains dalam Kurikulum Memperkuat Pendidikan Karakter Siswa Sekolah Dasar. Penguatan Pendidikan Karakter Pada Siswa
Dalam Menghadapi Tantangan Global, 0291, 223-230.

Of, D., \& Education, C. (2020). Pengembangan pendidikan karakter melalui pendekatan behaviorisme berbasis neurosains di sd muhammadiyah purbayan. 05, 38-53.

Rivalina, R. (2020). PENDEKATAN NEUROSAINS Neuroscience Approaches Improving High Order Thinking Skills of Basic. 08(01), 83-109.

Rofdli, M. F. (2020). Tafsir Verses Neurosains ( The 'Aql in the Qur ' an and its Relevance to the Development of Critical Thinking in Islamic Education ). 5(1), 138152. https://doi.org/10.32505/tibyan.

Saifurrahman. (2019). Desain Pembelajaran Keagamaan Islam Berbasis Neurosains. Al-Murabbi, 6(1), 55-73.

Wathon, A. (2016). Neurosains dalam pendidikan. JURNAL LENTERA: Kajian Keagamaan, Keilmuan Dan Teknologi, 14(1), 284-294. https://www.neliti.com/publicatio ns/177272/neurosains-dalampendidikan

Wijaya Hengki. (2018). Pendidikan Neurosains Dan Implikasinya Dalam Pendidikan Masa Kini. Pendidikan Dasar, 2(March), 119.

Wulandari, A., \& Suyadi, S. (2019). Pengembangan Emosi Positif Dalam Pendikan Islam Perspektif Neurosains. Tadrib: Jurnal Pendidikan Agama Islam, 5(1), 51-67. https://doi.org/10.19109/tadrib.v5i 1.3016 